\title{
Physiological aging in the Icelandic population of the ocean quahog Arctica islandica
}

\author{
Julia Strahl, Eva Philipp, Thomas Brey, Katja Broeg, Doris Abele*
}

Alfred-Wegener-Institute for Polar and Marine Research, Department of Biosciences, 27570 Bremerhaven, Germany

\begin{abstract}
The ocean quahog Arctica islandica is one of the longest-living and slowest-growing marine bivalves. The oldest specimens obtained for the present study approached $200 \mathrm{yr}$. To achieve such a long lifespan, accumulation of oxidative damage markers in tissues must ideally be maintained at low levels over time, because the accumulating debris disturbs cellular functions. We investigated shell growth and cellular aging in an Icelandic population of A. islandica. Specifically, we analyzed protein carbonyl concentration as a marker for the oxidative deterioration of tissue proteins, and the accumulation of the fluorescent age pigment lipofuscin over quahog lifetime in gill, mantle and adductor muscle. The very slow growth rates of $A$. islandica correlate with very efficient maintenance of body proteins compared to other, faster aging bivalves. Lipofuscin granules accumulated mainly in connective tissues of gill and mantle. Lowest lipofuscin accumulation was found in the adductor muscle, and there, only outside the myofibrils. Consistent with the pleiotropic theory of aging, A. islandica seems to trade slow growth and late onset of reproduction for a very efficient autophagic potential that mitigates oxidative damage accumulation and supports long lifetime and presumably reproduction in very old ocean quahog.
\end{abstract}

KEY WORDS: Arctica islandica $\cdot$ Ocean quahog $\cdot$ Growth $\cdot$ Aging $\cdot$ Lipofuscin $\cdot$ Protein oxidation

\section{INTRODUCTION}

Marine bivalves, especially from cold temperate and polar seas, can reach outstandingly long life spans (>300 yr) among aquatic ectotherms (Brey 1999). Finch (1990) put such species in a 'negligible aging' senescence category, indicating that proliferation continues slowly and persistently in most tissues until very old age. Variable environmental stress levels (temperature, light, food availability) affecting populations from different geographical locations, or differing levels of stress that individuals in these populations experience through predator attack or competition, can stochastically modify the process of aging in bivalves and populations, and differentially shorten or lengthen individual life expectancy. Thus, populations within a stressful environmental setting can exhibit a life expectancy distinctly lower than mean longevity in the species. In fact, once a species' longevity under optimal conditions is known, mean life expectancy of individuals in that population can serve as an indicator of the level of stress being experienced. This, and the fact that shells of long-lived cold-temperate bivalves are increasingly used as environmental archives (Richardson et al. 2001, Schöne et al. 2005), have raised interest in bivalve life strategies, as well as in the physiological changes in cells and tissues of aging bivalves. Recent work from our laboratory (Philipp et al. 2005a,b, Philipp et al. 2006) indicates that physiological aging in marine mud-dwelling bivalves is in line with the 'Free Radical - Rate of Living' theory established by Pearl (1928) and Harman (1956). This theory links the process of cellular aging to the rate of metabolic oxygen consumption that, in turn, determines the rate of mitochondrial release of hazardous reactive oxygen species (ROS) and shortens bivalve life expectancy. As in mammals (Terman \& Brunk 2005), accumulation of free radical damage markers is viewed as the major cause of aging in bivalves. In contrast, higher levels of enzymatic antioxidants and free radical scavengers, such as glutathione, support longer species life expectancy (Philipp et al. 2005a). 
We investigated physiological aging of the mud clam Arctica islandica (ocean quahog), one of the longestliving and slowest growing of the marine bivalves. Individuals over $100 \mathrm{yr}$ old are commonly found, and an outstanding maximum life span of $>300$ yr has been reported (Schöne 2003, Schöne et al. 2004). The extraordinary longevity and wide geographical distribution of A. islandica render it an interesting species for ecophysiological studies into the relative importance of extrinsic (environmental, e.g. temperature) and intrinsic (e.g. genetic or behavioural) factors in modifying animal physiology and altering the velocity of aging in ectotherms. In this paper, we present the first set of data from a study of physiological aging in A. islandica. Agedependent oxidative damage of proteins (protein oxidation) and accumulation of lipofuscin (end product of lipid peroxidation, also called 'fluorescent age pigment') in gill, mantle and adductor muscle of young (5 to $11 \mathrm{yr}$ ) and old (110 to $192 \mathrm{yr}$ ) A. islandica individuals from a cold-boreal North Icelandic population were measured. Both parameters are indicative of cellular maintenance through autophagic activity (i.e. autodigestion processes), and lipofuscin accumulation in connective tissues has previously been shown to correlate with age in long-lived bivalves (Lomovasky et al. 2002). Counting the annual internal growth bands in the shell of each individual, we were able to distinguish different ages among similarly sized individuals (Thompson et al. 1980a). We were interested to know if keeping the levels of oxidative damage products low forms part of the strategy employed by the ocean quahog to enable such extreme longevity, and whether or not there are tissuespecific differences in the aging process.

\section{MATERIALS AND METHODS}

Quahog collection and maintenance. Ocean quahog Arctica islandica were collected in August 2004 and in May 2005 northeast of Iceland $\left(66^{\circ} 01.54^{\prime} \mathrm{N}\right.$, $14^{\circ} 50.98^{\prime} \mathrm{W}$ ) between 14 and $22 \mathrm{~m}$ water depth using a hydraulic dredge. Water temperature on the sampling date was $4^{\circ} \mathrm{C}$ in May 2005 and $9^{\circ} \mathrm{C}$ in August 2004. The quahog were transported in cooling boxes to the Sandgerdi Marine Centre, Iceland, where they were kept at constant temperature $\left(9^{\circ} \mathrm{C}\right)$ and salinity (34.9 psu) in $400 \mathrm{l}$ tanks for $7 \mathrm{~d}$. On Day 7, quahog were dissected and gill and mantle were snap frozen in liquid nitrogen for biochemical analysis. Protein oxidation and lipofuscin were analyzed only in quahog sampled in 2005. Tissues were frozen for determination of protein carbonyl content and samples of gill, mantle and adductor muscle were fixed in Bakers formalin for $24 \mathrm{~h}$ and stored in gum sucrose until further processing for histological determination of lipofuscin granule accumulation. Shells of all individuals from 2004 and 2005 were cleaned and numbered for later age determination and assignment to the samples for biochemical analysis. Samples were transported to the Alfred-Wegener-Institute in Bremerhaven, Germany, for analysis.

Determination of individual age and growth. Individual age was determined from internal shell growth bands in 179 sampled shells, collected in August 2004 and in May 2005, following the procedure of Mutvei et al. (1994) and Schöne et al. (2004). The right shell valve was embedded in epoxy resin and sectioned along the axis of maximum shell growth (height $H$ ) with a Buehler low-speed diamond saw. Cross-sections were ground on lapidary wheels using grits of P400, P1200, P2400 and P4000 grade and subsequently polished using a polycristaline diamond suspension of 1 and $0.1 \mu \mathrm{m}$. Annual shell growth bands (see Schöne et al. 2004 for verification of annual band formation) were counted using a stereomicroscope at 10 to $80 \times$ magnification.

We fitted the general growth model of Schnute (1981) to the size-at-age data $\left(S_{t}\right.$ versus age $\left.t\right)$ by means of the nonlinear iterative Newton algorithm:

$$
S_{t}=\left\{Y_{1}^{\mathrm{B}}+\left(Y_{2}^{\mathrm{B}}-Y_{1}^{\mathrm{B}}\right) \times\left[\frac{1-\mathrm{e}^{-\mathrm{A} \times\left(t-t_{1}\right)}}{1-\mathrm{e}^{-\mathrm{A} \times\left(t_{2}-t_{1}\right)}}\right]\right\}^{1 / \mathrm{B}}
$$

The model has 2 constants: A (time ${ }^{-1}$ ), and B (dimensionless); and the size parameters $Y_{1}(\mathrm{~mm})$ and $Y_{2}$ $(\mathrm{mm})$. The 2 age values, $t_{1}$, and $t_{2}$, are chosen by the user, e.g. youngest and oldest individual in sample. The starting values of $Y_{1}$ and $Y_{2}$ are set accordingly. Special cases of the Schnute model resemble historical growth models such as the von Bertalanffy, Richards, or Gompertz models. For our study, the Schnute model indicated that the von Bertalanffy growth model fitted the data best:

$$
H_{t}=H_{\infty} \times\left(1-\mathrm{e}^{-\mathrm{K} \times\left(t-t_{0}\right)}\right)
$$

where $H_{\infty}=$ asymptotic shell height, $\mathrm{K}=$ growth constant, $t=$ age, and $t_{0}=$ age at which height is zero.

Determination of protein carbonylation. Protein carbonylation in 16 young ( 5 to $7 \mathrm{yr}$ ) and 17 old (110 to 192 yr) individuals was measured after Levine et al. (1990). For this analysis, 150 to $300 \mathrm{mg}$ tissue were homogenised in $1 \mathrm{ml}$ of $50 \mathrm{mM}$ HEPES homogenization buffer, containing $125 \mathrm{mM} \mathrm{KCl}, 1.25 \mathrm{mM}$ EDTA, $0.6 \mathrm{mM} \mathrm{MgSO}_{4}$ and protease inhibitors $\left(0.5 \mu \mathrm{g} \mathrm{ml}^{-1}\right.$ leupeptine, $0.7 \mu \mathrm{g} \mathrm{ml}^{-1}$ pepstatine, $40 \mu \mathrm{g} \mathrm{ml}^{-1}$ phenylmethylsulfonyl fluoride, $0.5 \mu \mathrm{g} \mathrm{ml}^{-1}$ aprotinin, $0.44 \mathrm{mg}$ $\mathrm{ml}^{-1}$ EDTA, $160 \mu \mathrm{g} \mathrm{ml}^{-1} \mathrm{MgSO}_{4} \times 7 \mathrm{H}_{2} \mathrm{O}, \mathrm{pH}$ 7.4), using a glass homogenizer (IKA Eurostar) at $300 \mathrm{rpm}$. Subsequently, $4 \mathrm{ml}$ homogenization buffer was added and the homogenate was centrifuged at $31000 \times g$ (Ultracentrifuge, Beckmann L7-80) for $22 \mathrm{~min}$ at $4^{\circ} \mathrm{C}$. Two replicates of $0.4 \mathrm{ml}$ each from the supernatant 
were incubated with $1.4 \mathrm{ml}$ of acidic DNP (10 mM 2,4-dinitrophenylhydrazine in $2 \mathrm{M} \mathrm{HCl}$ ) at room temperature for $1 \mathrm{~h}$ to let DNP bind to the carbonyl groups. Blanks were run with $\mathrm{HCl}$ only. Following the incubation, protein was precipitated with $0.2 \mathrm{ml} 100 \%$ trichloroacetic acid (TCA) and centrifuged for $5 \mathrm{~min}$ at $11000 \times g$. The protein pellet was washed 3 times with ethanol:ethylacetate (1:1) and the final pellet left to dry out completely before being re-dissolved in $0.6 \mathrm{ml}$ of guanidine hydrochloride $(6 \mathrm{M}$ in $20 \mathrm{mM}$ potassium phosphate buffer at $\mathrm{pH}=2.5)$ at $4^{\circ} \mathrm{C}$ during $12 \mathrm{~h}$. After a final centrifugation $\left(11000 \times g, 5 \mathrm{~min}, 4^{\circ} \mathrm{C}\right)$, the carbonyl content in each sample and blank was measured spectrophotometrically at $360 \mathrm{~nm}$ (molar extinction coefficient $\varepsilon=22.000 \mathrm{M}^{-1} \mathrm{~cm}^{-1}$ ). To relate carbonyl content to the amount of extracted proteins in each sample, the protein content was subsequently measured using Bradford's (1976) method.

Histological investigation of lipofuscin accumulation. Accumulation of lipofuscin was assessed histologically in 8 young (5 to $11 \mathrm{yr}$ ) and 8 old (110 to $192 \mathrm{yr}$ ) individuals. Samples of $5 \times 5 \times 5 \mathrm{~mm}$ of gill, mantle and adductor muscle were transferred to histocettes and fixed in Bakers formalin (100 ml formaldehyde $40 \%$ and $20 \mathrm{~g} \mathrm{Ca}\left(\mathrm{CH}_{3} \mathrm{COO}\right)_{2}$ in $1 \mathrm{l}$ distilled water) for $24 \mathrm{~h}$. Subsequently, samples were transferred to a gumsucrose solution (300 g sucrose and $10 \mathrm{~g}$ gum Arabic in 11 distilled water) and transported to the AlfredWegener-Institute in Bremerhaven, where samples were maintained at $4^{\circ} \mathrm{C}$ until further processing.

For embedding, samples were washed twice with $0.2 \mathrm{M}$ phosphate buffer ( $\mathrm{pH} 7.4$ ) for $30 \mathrm{~min}$. Samples were dehydrated by $2 \times 15 \mathrm{~min}$ in $70 \%$ and $2 \times 15 \mathrm{~min}$ in $100 \%$ acetone immersions. Each sample was then transferred into $5 \mathrm{ml}$ monomer solution $(80 \mathrm{ml}$ 2-hydroxyethyl-methacrylic acid, $12 \mathrm{ml}$ 2-butoxyethanol, $0.27 \mathrm{~g}$ benzoylperoxide) and left for $12 \mathrm{~h}$. Subsequently, samples were transferred to an embedding form and $0.1 \mathrm{ml}$ of polymerization activator solution (polyethylene glycol 200 and N,N-dimethyaniline, 10:1) were added to each $5 \mathrm{ml}$ of monomer solution. Samples were left to polymerise at $4^{\circ} \mathrm{C}$ for $12 \mathrm{~h}$ and then dried $24 \mathrm{~h}$ in the fume hood before being cut into $2 \mu \mathrm{m}$ slices with a rotation microtome (Leica, RM 2145). Lipofuscin was detected by Schmorl-staining modified after Pearse (1960). Sections of different tissues were washed for $10 \mathrm{~min}$ in distilled water and stained for $10 \mathrm{~min}$ in a mix of $100 \mathrm{ml}$ of solution A (500 mg iron-(III)-chloride in $50 \mathrm{ml}$ distilled water) and $100 \mathrm{ml}$ of solution B (500 mg potassium-iron-cyanide in $50 \mathrm{ml}$ distilled water). Then, sections were placed for 2 min in $1 \%$ acetic acid, washed for 10 min under running water, and then washed 3 times in distilled water. Subsequently, sections were dried, fixed in glycerine gelatine (Merck, Microscopy Kaiser glycerine gelatine) and analyzed by a Zeiss Axioscope light microscope equipped with a KS300 Zeiss image analysis software. The percentage of tissue area occupied by lipofuscin granules was assessed.

Statistics. Protein oxidation data were tested for normality (Kolmogorov-Smirnov test) and homogeneity of variances (Bartlett's test). The effects of tissue type and age on the lipofuscin content were tested by full interaction analysis of covariance (ANCOVA) using the statistical programme package JMP 5.0.1 (SAS), i.e. $\ln$ (lipofuscin content) versus tissue type (gill, mantle, muscle) and covariate ln(age).

\section{RESULTS}

\section{Individual growth}

Individual growth is best described by the von Bertalanffy growth model (Fig. 1):

$$
H_{t}=86\left(1-\mathrm{e}^{-0.057(t+0.399)}\right) ; \mathrm{N}=179, \mathrm{r}^{2}=0.933
$$

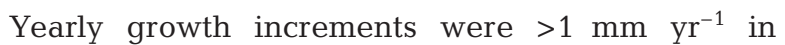
young quahog $(<12 \mathrm{yr})$, but $<0.5 \mathrm{~mm} \mathrm{yr}^{-1}$ at the age of $40 \mathrm{yr}$.

\section{Age dependence of protein carbonylation (CO group formation)}

Young quahog (5 to $8 \mathrm{yr}$, mantle $\mathrm{N}=10$, gill $\mathrm{N}=7$ )

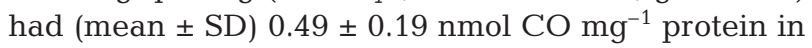

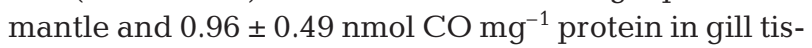
sue. Old individuals (110 to $192 \mathrm{yr}$, mantle and gill $\mathrm{N}=$ 8) had a mantle content of $0.58 \pm 0.46 \mathrm{nmol} \mathrm{CO} \mathrm{mg} \mathrm{mg}^{-1}$ protein and a gill content of $1.14 \pm 0.54 \mathrm{nmol} \mathrm{CO} \mathrm{mg}^{-1}$ protein. $\mathrm{CO}$ content did not differ significantly between age groups or tissue types ( $p>0.05)$.

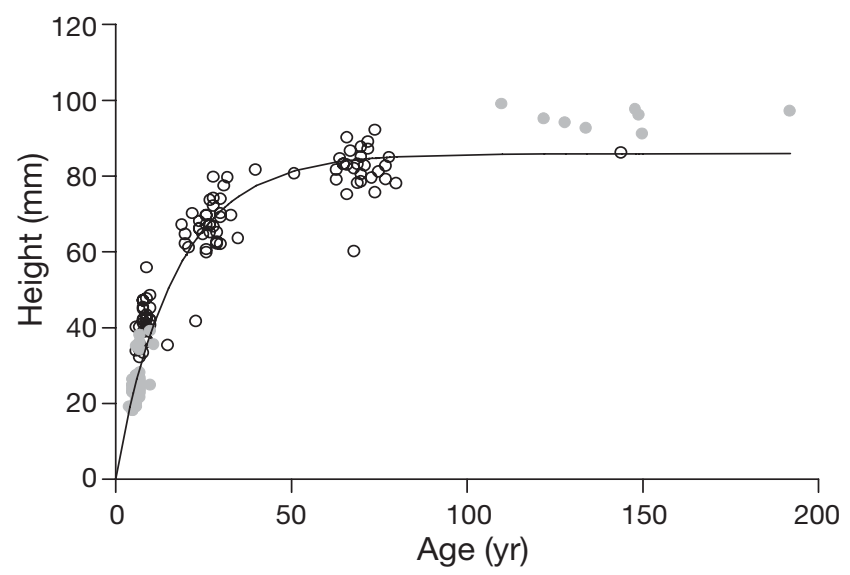

Fig. 1. Arctica islandica. Von Bertalanffy growth model of the northern Iceland population based on 2 different sampling events in August 2004 (०) and May 2005 (॰). N = 179, $\mathrm{r}^{2}=0.933$ 


\section{Lipofuscin accumulation}

Lipofuscin content was measured in gill, mantle and adductor muscle. Accumulation of lipofuscin in mantle (Fig. 2a,d) and gill (Fig. 2b,e) sections was not homogenous, but granules were concentrated in the connective tissue below the epidermis. The percentages (see Fig. 3) refer to only those areas of the tissues that contained granules (i.e. epidermis was not included). Adductor muscle was cut vertically to the fibres, and lipofuscin was encountered only in the sarcoplasmatic interstice (Fig. 2c,f) between myofibrils. We found that individual muscle fibres increased in size from $15 \times$ $5 \mu \mathrm{m}$ in young to $20 \times 15 \mu \mathrm{m}$ in older specimens. Histological evaluation of the density of lipofuscin granules in muscle was done for the interstitial compartment between the myofibrils which comprised $<30 \%$ of the whole tissue in young and old quahog.

Lipofuscin content was significantly different in all 3 tissues (gill > mantle > muscle) and increased significantly over bivalve age (Fig. 3). The rate of increase with age did not differ between tissues (no significant interaction term, $p=0.117$, Fig. 3): $\ln ($ lipo $)=-3.070+$ $0.657 \times \ln ($ age $)+1.134 \times$ Dgill $+0.485 \times$ Dmantle -

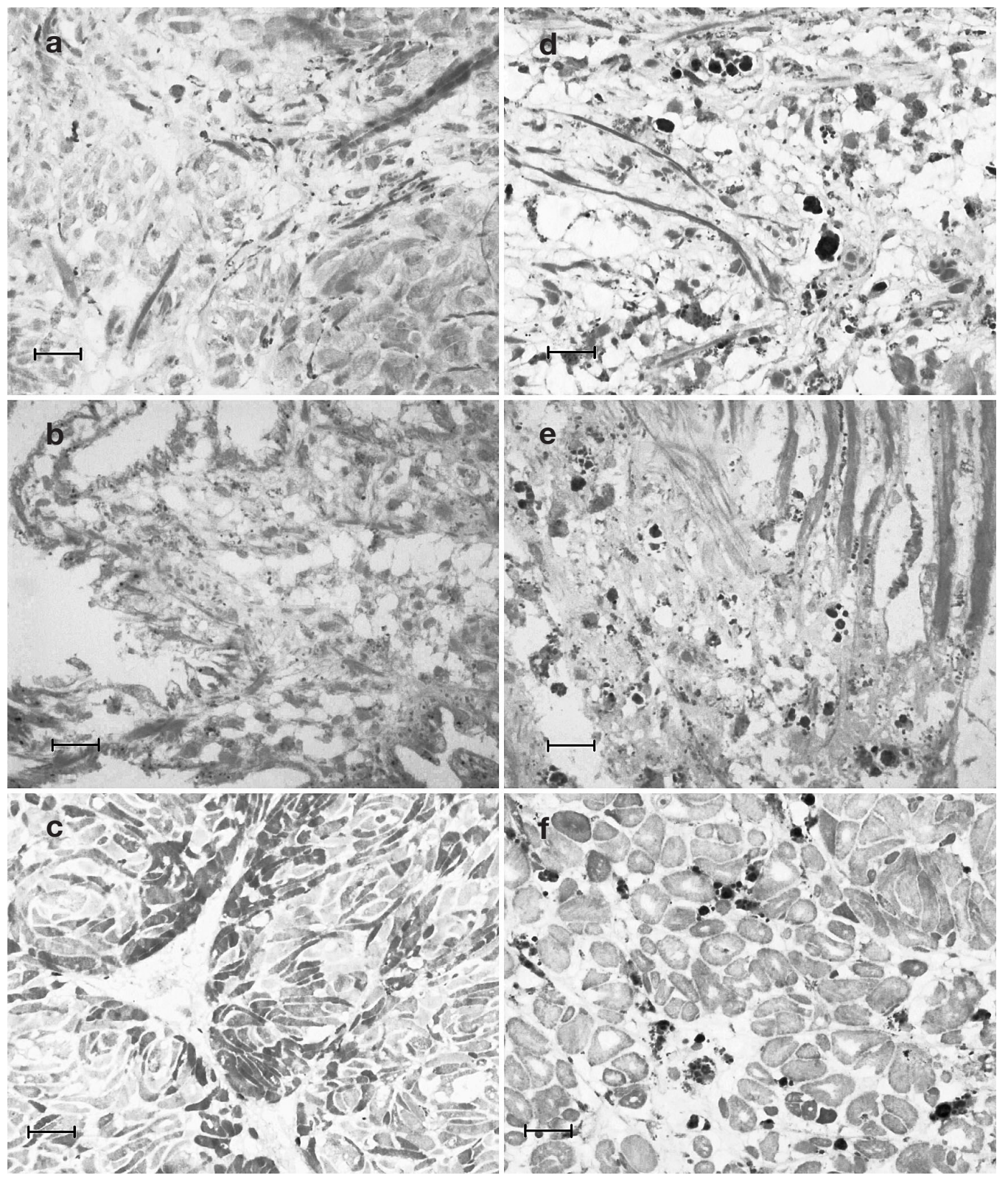

Fig. 2. Arctica islandica. Tissue slices from $(\mathrm{a}, \mathrm{d})$ mantle, $(\mathrm{b}, \mathrm{e})$ gill and $(\mathrm{c}, \mathrm{f})$ adductor muscle, embedded in gum sucrose and Schmorl-stained to visualize lipofuscin granules as irregular dark blue spots (= black spots in panels above). (a,b,c) Young quahogs $(7 \mathrm{yr})$ vs. (d,e,f) old quahogs $(122,148$ and $149 \mathrm{yr}$, respectively). Scale bars: $20 \mu \mathrm{m}$ 


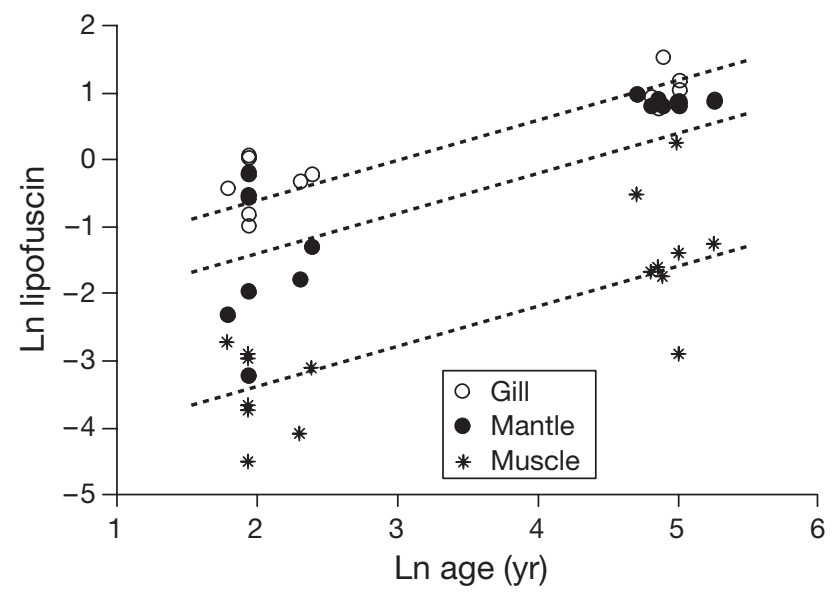

Fig. 3. Arctica islandica. Lipofuscin accumulation (fraction of lipofuscin granules in tissue slices) in mantle, gill and adductor muscle. Trend lines indicate no difference in the rate of lipofuscin accumulation between different tissues

$1.919 \times$ Dmuscle; $\mathrm{N}=48, F=79.44$, all $\mathrm{p}<0.001$, where Dgill, Dmantle and Dmuscle represent 'dummy' variables $(1=$ this tissue, $0=$ not this tissue $)$.

Gills of old quahog (>100 yr) had the highest density of lipofuscin granules, followed by the mantle tissue, whereas lipofuscin accumulation in muscle was limited to the connective tissue between myofibrils. Even though only this part of the tissue was analyzed, the density of lipofuscin was low in muscle slices, but the rate of accumulation was the same as in mantle and gill.

\section{DISCUSSION}

In the present study, the oldest quahog individual was 192 yr old. Such extraordinary longevity requires fundamental behavioural or life history traits that support selection against aging. One important strategy would be to trade vigour, rapid growth, and reproductive output in young quahog for increased longevity. Fig. 4 depicts growth constant $\mathrm{K}$ of the von Bertalanffy growth function for 147 different bivalve populations (Brey 1999) and shows that Arctica islandica is one of the slowest growing bivalves worldwide. Such slow growth may be the trade-off for slower aging and stable or increased reproductive output in later life, as documented for fish (e.g. Atlantic cod, Olsen et al. 2005; for a review see Pauly et al. 2002) and for long-lived turtles (Congdon et al. 2003). In both cases, older females increase reproductive output (egg production, clutch size or reproductive frequency) with age. Also, in long-lived iteroparous bivalves, reproductive output is known to increase in successive breeding seasons (Browne \& Russell-Hunter 1978),

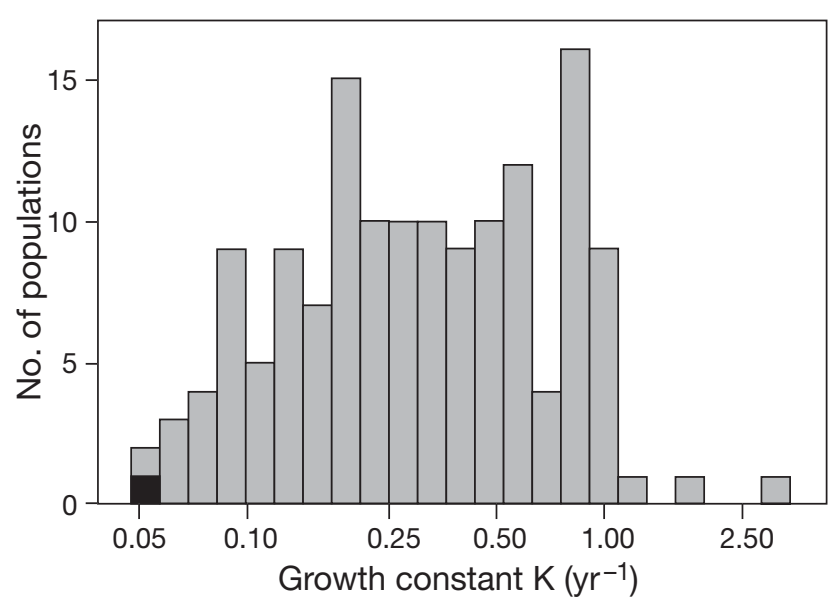

Fig. 4. Distribution of growth constant K of the von Bertalanffy growth function (VBGF) of 147 different bivalve populations from all over the world. Data are from a databank started by Brey (1999). Logarithmic scale on $x$-axis. Black bar: Arctica islandica, grey bars: others

the 'trade-offs' consisting of deferred maturation and general energy saving behaviour. Energy saving in this case means low metabolic rates involving periods of actual metabolic rate depression, as shown for A. islandica from the Irish Sea (Taylor 1976). Gonadal maturation in the ocean quahog is slow and first spawning occurs between 10 and $14 \mathrm{yr}$ of age (Thompson et al. 1980b). Furthermore, there is a general trend observable in aquatic ectotherms towards increased maximum life spans in the cold when comparing temperate and cold water species of similar lifestyle (Brey 1991, Brey et al. 1995, Ziuganov et al. 2000, Cailliet et al. 2001, La Mesa \& Vacchi 2001), and deferred maturation and late reproductive output may form part of this life extension in cold water. This also implies a delay in physiological ageing in the cold. Lower metabolic rates at low temperatures reduce reactive oxygen species (ROS) propagation from mitochondrial respiration, thereby presumably supporting slower rates of physiological ageing (Abele \& Puntarulo 2004). In the case of the ocean quahog, certainly a cold water species, it is likely that the energy saving, oxyconforming behaviour confers an adaptive value for life in the cold and, at the same time, increases longevity to support reproductive output in late age; it may also have a further slowing effect on physiological aging in addition to the effect of temperature.

Taken together, these attributes of Arctica islandica suggest it is a perfect example of antagonistic pleiotropy, a theory of longevity, established by Williams (1957) and later detailed by Kirkwood (2005), and originally applied to aging-studies models such as Drosophila (for a review of evolutionary genetics of longevity see Zwaan 1999). 
As mentioned above, one mechanistic basis underlying such slow aging involves mitigation of ROS generation during mitochondrial oxygen turnover and the accumulation of oxidative damage by cellular maintenance processes. The mean protein carbonyl concentrations in mantle tissue, ranged lower than in shorter living and faster growing soft shell clams like Mya arenaria and Laternula elliptica, or scallops like Aequipecten opercularis and Adamussium colbecki (see Table 1). Moreover, the age-dependent change in carbonyl concentration per $\mathrm{mg}$ protein in A. islandica did not reach significance in either gill or mantle tissue between $8 \mathrm{yr}$ old, and 110 to $190 \mathrm{yr}$ old specimens. In contrast, in the mantle tissue of the Antarctic soft shell clam L. elliptica $(\mathrm{K}=0.06)$, carbonylated proteins accumulate linearly over lifetime with nmol carbonyl $\mathrm{mg}^{-1}$ protein $=0.052 \times$ age +1.213 in mantle tissue $(\mathrm{n}=28$, $\mathrm{p}<0.001$; Philipp et al. 2005a). A 40 yr old L. elliptica

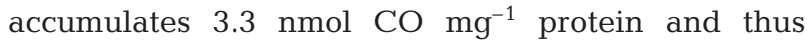
around twice as much as the oldest $A$. islandica we sampled. However, linear accumulation with age is not always found, and in the fast growing soft shell clam $M$. arenaria from North Sea intertidal areas $(K=0.12)$, protein carbonyl concentration in mantle tissue decreased significantly between 3 and $9 \mathrm{yr}$ of age (Philipp et al. 2005a). We interpret this as indication for rapid cellular division and continuous protein turnover in more rapidly growing clams.

Low protein carbonyl concentrations in Arctica islandica are possibly due to less active protein oxidation and, therefore, linked to lower metabolic oxygen turnover and oxidative stress. Alternatively, low carbonyl accumulation in a tissue might indicate very efficient removal of carbonylated proteins through proteasomal and autophagic processes. Both explanations may apply, and the fact that the density of lipofuscin granules increased over age in all 3 tissues speaks for active autophagy of damaged mitochondria and other cellular structures (see Terman \& Brunk 2005 for

Table 1. Mean life span (MLSP) and (mean \pm SD) protein carbonyl concentrations in the mantle tissue of 5 different bivalve species, including the Arctica islandica population investigated in this study. For all species, a mean value is given for the protein carbonyl concentration for the whole age range sampled; except for A. islandica, only data of old

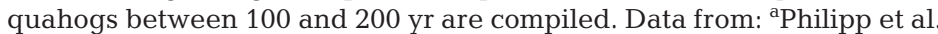
(2005a), bthis study, 'Philipp et al. (2006)

\begin{tabular}{|llcc|}
\hline Species & Location & $\begin{array}{c}\text { MLSP } \\
(\mathrm{yr})\end{array}$ & $\begin{array}{c}\text { Carbonyls } \\
\left(\mathrm{mg}^{-1} \text { tissue protein }\right)\end{array}$ \\
\hline Mya arenaria $^{\mathrm{a}}$ & North Sea & 13 & $1.154 \pm 0.2992$ \\
Laternula elliptica $^{\mathrm{a}}$ & Antarctic & 36 & $1.875 \pm 0.5747$ \\
Arctica islandica $^{\mathrm{b}}$ & Iceland & $>200$ & $0.58 \pm 0.46$ \\
${\text { Aequipecten } \text { opercularis }^{\mathrm{c}}}^{\mathrm{C}}$ & Irish Sea & 8 to 10 & $1.016 \pm 0.07263$ \\
Adamussium colbecki $^{\mathrm{C}}$ & Antarctic & 45 & $1.319 \pm 0.1815$ \\
\hline
\end{tabular}

a review). Carbonylated proteins seem to underly efficient autophagic removal in A. islandica, preventing significant accumulation in any of the 3 investigated tissues. The different intensity of lipofuscin accretion in different tissues (different intercepts in Fig. 3) is indicative of better protection and maintenance of muscle than of mantle and gill. Either less muscle mitochondria become dysfunctional, leading to less lipofuscin-carrying residual bodies in the muscle, or residual bodies are removed from the muscle tissue by phagocytes and stored in other tissues. This confers an advantage to muscle tissue because densely accumulating lipofuscin granules have been found to disturb organ functions. They impair the autophagic processes and hamper diffusion and transport within the cell, because degrading hydroxylase enzymes are confined in these lipofuscin containing lysosomes, and the cytosol outside becomes deprived of autophagic potential (see Terman \& Brunk 2005 for a review). In adductor muscle of $A$. islandica, lipofuscin containing lysosomes were found only in the cells outside the myofibrils. In contrast, the myofibrils themselves were essentially free of any lipofuscin, which may be a prerequisite for the preservation of muscle contractive power. This is consistent with findings from senescent mammalian cardiac myocytes, which display apparently intact myofibrils in spite of abundant lipofuscin deposits and damaged mitochondria (Terman et al. 2003). In Fig. $2 \mathrm{f}$ it is easy to see that myofibril diameter increased in older quahog. However, the ratio of contractive elements to accompanying interstitial cells containing the lipofuscin remained the same in young and old quahog. This means the data can be extrapolated to the whole muscle and are thus comparable to lipofuscin accumulation in gill and mantle. The slope of accumulation in Fig. 3 indicates no difference in the accumulation rate between the 3 tissues. As yet, we have been unable to sample neuronal tissues from the ocean quahog, which would have been interesting to compare with respect to age pigment accumulation from the ocean quahog.

We have shown that slow growth rates, accompanied by sustained protection of body proteins from oxidative degradation even at old age, as well as effective disposal of oxidative damage waste products in the lysosomal bodies, are important traits of longevity in the bivalve Arctica islandica. Importantly, the lipofuscin granules are located in metabolically less active connective and interstitial tissues, where they are less likely to impair metabolic and diffusive processes of the organs. Good preservation of tissue protein could be due to low mitochondrial ROS output at low metabolic activity of the mud clam, and transient metabolic rate depres- 
sion may be an important behavioural strategy here (see Taylor 1976). Elevated antioxidant protection and autophagic cell clean-up may further mitigate oxidative damage and support tissue maintenance over the long lifetime of $A$. islandica. Altogether, this seems to be part of the pleiotropic life strategy of the ocean quahog, favouring longevity and enhanced reproductive output at old age over rapid growth and activity in young quahog.

Acknowledgements. The authors thank Gudmundur Vidir Helgason and Halldor Palmar Halldorsson from Sandgerdi Marine Station, University of Iceland; Gudrun G. Thorarinsdottir from the Marine Research Institute in Reykjavik, Thorsteinn Thorbergsson and Noi for their support in sampling and maintenance of the experimental quahog during the field expeditions to Iceland. Nadja Neubert gave a helping hand on the second field trip to Iceland. Angela Koehler kindly provided support from her histological laboratory. Thanks to Stefanie Meyer, Sieglinde Bahns and Kerstin Beyer for valuable technical support.

\section{LITERATURE CITED}

Abele D, Puntarulo S (2004) Formation of reactive species and induction of antioxidant defense systems in polar and temperate marine invertebrates and fish. Comp Biochem Physiol 138A(4):405-415

Bradford MM (1976) A rapid and sensitive method for the quantitation of microgram quantities of protein utilizing the principle of protein-dye binding. Anal Biochem 72: 248-254

Brey T (1991) Population dynamics of Sterechinus antarcticus (Echinodermata: Echinoidea) on the Weddell Sea shelf and slope, Antarctica. Antarct Sci 3(3):251-256

Brey T (1999) Growth performance and mortality in aquatic benthic invertebrates. Adv Mar Biol 35:153-223

Brey T, Pearse J, Basch L, McCintock J, Slattery M (1995) Growth and production of Sterechinus neumayeri (Echinoidae: Echinodermata) in McMurdo Sound, Antarctica. Mar Biol 124:279-292

Browne RA, Russel-Hunter WD (1978) Reproductive effort in molluscs. Oecologia 37:23-27

Cailliet GM, Andrews AH, Burton EJ, Watters DL, Kline DE, Ferry-Graham LA (2001) Age determination and validation studies of marine fishes: Do deep-dwellers live longer? Exp Gerontol 36:739-764

Congdon JD, Nagle RD, Kinney OW, van Loben Sels RC, Quinter T, Tinkle DW (2003) Testing hypotheses of aging in long-lived painted turtles (Chrysemys picta). Exp Gerontol 38:765-772

Finch CE (1990) Longevity, senescence, and genome. University of Chicago Press, Chicago, IL

Harman D (1956) Aging: a theory based on free radical and radiation biology. J Gerontol 11:298-300

Kirkwood TBL (2005) Understanding the odd science of aging. Cell 120:437-447

La Mesa M, Vacchi M (2001) Review. Age and growth of high Antarctic notothenioid fish. Antarctic Sci 13:227-235

Levine RL, Garland D, Oliver CN, Amici A and 5 others (1990) Determination of carbonyl content in oxidatively modified proteins. Methods Enzymol 186:464-478

Lomovasky BJ, Morriconi E, Brey T, Calvo J (2002) Individual age and connective tissue lipofuscin in the hard clam Eurhomalea exalbida. J Exp Mar Biol Ecol 276:83-94

Mutvei H, Westermark T, Dunca E, Carell B, Forberg S, Bignert A (1994) Methods for the study of environmental changes using the structural and chemical information in molluscan shells. Bull Inst Océanogr Monaco 13:163-186

Olsen EM, Lilly GR, Heino M, Morgan MJ, Brattey J, Dielmann U (2005) Assessing changes in age and size at maturation in collapsing populations of Atlantic cod (Gadus morhua). Can J Fish Aquat Sci 62:811-823

Pauly D, Christensen V, Guénette S, Pitcher TJ, Sumaila UR, Walters CJ, Watson R, Zeller D (2002) Towards sustainability in world fisheries. Nature 418:689-695

Pearl R (1928) The rate of living. Alfred Knopf, New York

Pearse AGE (1960) Histochemistry, theoretical and applied. Littel Brown \& Co, Boston, MA

Philipp E, Brey T, Pörtner HO, Abele D (2005a) Chronological and physiological ageing in a polar and a temperate mud clam. Mech Ageing Dev 126:589-609

Philipp E, Pörtner HO, Abele D (2005b) Mitochondrial ageing of a polar and a temperate mud clam. Mech Ageing Dev 126:610-619

Philipp E, Heilmayer O, Brey T, Abele D, Pörtner HO (2006) Physiological ageing in a polar and a temperate swimming scallop. Mar Ecol Prog Ser 307:187-198

Richardson CA, Chenery SRN, Cook JM (2001) Assessing the history of trace metal $(\mathrm{Cu}, \mathrm{Zn}, \mathrm{Pb})$ contamination in the North Sea through laser ablation ICP-MS of horse mussel, Modiolus modiolus shells. Mar Ecol Prog Ser 211:157-167

Schnute J (1981) A versatile growth model with statistically stable parameters. Can J Fish Aquat Sci 38:1128-1140

Schöne BR (2003) A 'clam-ring' master-chronology constructed from a short-lived bivalve mollusc from the northern Gulf of California, USA. The Holocene 13:39-49

Schöne BR, Freyre Castro AD, Fiebig J, Houk SD, Oschman W, Kröncke I (2004) Sea surface water temperatures over the period 1884-1983 reconstructed from oxygen isotope ratios of a bivalve mollusk shell (Arctica islandica, southern North Sea). Palaeogeogr Palaeoclimatol Palaeoecol 212: $215-232$

Schöne BR, Houk SD, Freyre Castro AD, Fiebig J, Oschman W (2005) Daily growth rates in shells of Arctica islandica: assessing sub-seasonal environmental controls on a longlived bivalve mollusk. Palaios 20:78-92

Taylor AC (1976) Burrowing behaviour and anaerobiosis in the bivalve Arctica islandica (L.). J Mar Biol Assoc UK 56:95-109

Terman A, Brunk UT (2005) Autophagy in cardiac myocyte homeostasis, aging, and pathology. Cardiovasc Res 68: 355-365

Terman A, Dalen H, Eaton JW, Neuzil J, Brunk UT (2003) Mitochondrial recycling and aging of cardiac myocytes: the role of autophagocytosis. Exp Gerontol 38:863-876

Thompson I, Jones DS, Dreibelbis D (1980a) Annual internal growth banding and life history of the ocean quahog Arctica islandica (Mollusca: Bivalvia). Mar Biol 57:25-34

Thompson I, Jones DS, Ropes JW (1980b) Advanced age for sexual maturity in the ocean quahog Arctica islandica (Mollusca: Bivalvia). Mar Biol 57:35-39

Williams GC (1957) Pleiotropy, natural selection and the evolution of senescence. Evolution 11:398-411

Ziuganov V, Miguel ES, Neves RJ, Longa A and 6 others (2000) Life span variation of the freshwater pearl shell: a model species for testing longevity mechanisms in animals. Ambio 29:102-105

Zwaan BJ (1999) The evolutionary genetics of aging and longevity. Heredity 82:589-597 